\title{
UGDYMO TURINIO IVAIROVE் KAIP VEIKSNYS, SKATINANTIS UGDYTINIŲ MOTYVACIJĄ SPORTUOTI
}

\author{
Lauras Grajauskas ${ }^{1}$, Algirdas Čepulènas ${ }^{2}$ \\ Šiauliu universitetas ${ }^{1}$, Šiauliai, Lietuvos kūno kultūros akademija ${ }^{2}$, Kaunas, Lietuva
}

\begin{abstract}
Lauras Grajauskas. Socialinių mokslų (edukologijos) daktaras. Šiaulių universiteto Edukologijos fakulteto Kūno kultūros ir sporto eduko-
\end{abstract} logijos katedros lektorius. Mokslinių tyrimų kryptys: jaunujų sportininkų rengimo modeliavimas; sporto ir fizinio aktyvumo motyvacija.

\begin{abstract}
SANTRAUKA
Ugdymo turinys yra svarbus veiksnys, lemiantis mokiniu motyvacija. Ryšys tarp sportinio ugdymo turinio ¿̨vairovès ir vaiku motyvacijos sportuoti nepakankamai išnagrinètas. Jis dažniau nagrinèjamas formaliojo švietimo požiūriu, o neformaliojo — dažniau nusakomas teoriškai, nei grindžiamas konkrečiais empiriniais tyrimais. Tyrimo tikslas atskleisti ryš̨ tarp neformalaus ugdymo turinio ¿̇vairovès ir mokiniu motyvacijos sportuoti.

Pirmiausia buvo išnagrinèti dvieju savo veikla panašiu neformalaus švietimo büreliu —orientavimosi sporto ir sportinio turizmo - metiniai veiklos planai (6 orientavimosi sporto ir 4 turizmo). Pagal temas, temu turinio formuluotes išskirtos veiklos temu grupés, nagrinèti kiekybiniai ir kokybiniai dvieju büreliu veiklos skirtumai. Vèliau tiriama mokiniu motyvacija sportuoti. Iš viso buvo tiriami 104 12-14 metu amžiaus moksleiviai (68 orientacininkai ir 36 turistai). Motyvacija matuota sporto motyvacijos skale (Pelletier et al., 1995).

Nustatyta, kad sportinio turizmo būreliu programos yra išsamesnès, integruojančios daugiau skirtingu temu, didesné temu ¿̇vairovè, o orientavimosi sporto büreliu programos glaustesnès. Šešiose sporto motyvacijos subskalèse skirtumas tarp grupiu yra nereikšmingas, o nemotyvuotumo subskalès teiginiams labiau $(p<0,05)$ pritaré orientacininkai (2,19 $\pm 0,96$ balo) nei turistai (1,62 $\pm 0,59$ balo). Tiek orientavimosi, tiek sportinio turizmo bürelio mokiniai labiausiai pritarè pirmu triju subskaliu teiginiams, kurie indikuoja vidinès motyvacijos apraiškas (orientacininku vidiniu motyvu intensyvumas sieke - 3,91 balo, turistu - 3,99). Išorinę motyvacija indikuojančiu subskaliu vidutiniai jverčiai buvo kiek mažesni abiejose grupése ir labiau telkèsi apie atsakymo formuluotę ,nežinau “ (orientacininku vidurkis - 3,19 balo, turistu - 3,21).

Apibendrinant tyrimo rezultatus galima teigti, kad ugdymo turinio ¿̇vairové susijusi tik su sportuojančiu mokiniu nemotyvuotumu. Esant didesnei ugdymo turinio ¿̇vairovei, ugdytiniu nemotyvuotumas yra mažesnis.
\end{abstract}

Raktažodžiai: neformalus švietimas, motyvacija, ugdymo turinys, ¿̇vairové.

\section{IVADAS}

$\mathrm{N}$ eabejojama sporto, fizinio aktyvumo nauda vaikų ir paauglių asmenybei, sveikatai, fiziniu gebejjimu vystymuisi. Visgi daugeja tiesioginiu bei netiesioginiu irodymų, kad vaikų ir ypač paauglių fizinis aktyvumas mažejja (Dollman et al., 1999; Anderssen et al., 2005; Hallal et al., 2006). Aktualiais darosi tokie moksliniai tyrimai, kuriais atskleidžiami veiks- niai, turintys itakos mokinių sportinès veiklos ir fizinio aktyvumo motyvacijai. Motyvacijos stiprinimas - svarbi sportinio rengimo(-si) dalis (Malinauskas, 1998, 2003 a, 2003 b; Hardy et al., 2003; Weinberg, Gould, 2006; Ryan, Deci, 2007; Vallerand, 2007), nes tvirtinama, kad motyvacija yra vienas svarbiausių veiksnių, galinčių veikti ir sportinį rezultatą. 
Nagrinėjant motyvaciją sportuoti, dažniausiai remiamasi (Malinauskas, 2003 b; Weinberg, Gould, 2006) trimis laimejjimų motyvacijos teorijomis (laimejjimu poreikio, atribucijos, sékmès tikslų) ir apsisprendimo teorija. Ypač aktualu ugdymo turinio įvairovę kaip veiksni, skatinantị vaikų motyvaciją sportuoti, nagrinèti apsisprendimo teorijos požiūriu, kuria asmens motyvacija ir su ja susijęs elgesys aiškinami pagal šaltini, iš kur elgesys yra valdomas, lemiamas, reguliuojamas (Ryan, Deci, 2007; Vallerand, 2007). Iš esmès šaltiniai gali būti du: vidinis ir išorinis. Todèl mokantis, dirbant ar sportuojant, anot teorijos pradininku (Ryan, Deci, 2007), ryškèja dvi motyvacijos rūšys: vidinè ir išorinè.

Mokslininkai (Chen, Ennis, 2004; Alderman et al., 2006; Šarkauskienė, Adaškevičienè, 2008) nustato ryši tarp ivvairių ugdymo veiksnių ir ugdytinių motyvacijos bei fizinio aktyvumo poreikio. Pažymima, kad tokie veiksniai kaip ugdymo turinys ir ugdytojo elgsena labai svarbūs lemiant mokinių motyvaciją (Alderman et al., 2006). Visgi sportinio ugdymo turinio įvairovès ir vaikų motyvacijos sportuoti ryšio problema yra nepakankamai atskleista. Ši problema dažniau nagrinèjama formaliojo švietimo požiūriu, o neformalusis švietimas dažniau nusakomas teoriškai (Gilbertson et al., 2006) nei grindžiamas konkrečiais empiriniais tyrimais.

Tyrimo tikslas - atskleisti neformalaus ugdymo turinio įvairovès ir mokinių motyvacijos sportuoti ryši.

Hipotezè. Keliama prielaida, kad esant didesnei ugdymo ívairovei ugdytinių nemotyvuotumas mažesnis.

\section{TYRIMO METODIKA IR ORGANIZAVIMAS}

Tyrimas atliktas neformaliojo vaikų švietimo istaigoje - Šiauliu jaunuju turistu centre. Viena ugdymo įstaiga apsiribota siekiant pašalinti kitus veiksnius, galinčius paveikti tyrimo rezultatus. Pirmiausia buvo išnagrinèti dviejų savo veikla panašiu neformalaus švietimo būrelių — orientavimosi sporto ir sportinio turizmo - metiniai veiklos planai (6 orientavimosi sporto ir 4 turizmo). Pagal temas, temų turinio formuluotes išskirtos veiklos grupès, nagrinèti kiekybiniai ir kokybiniai dviejų būrelių veiklos skirtumai.

Pratybų metu buvo tiriama mokinių motyvacija sportuoti. Iš viso apklausti 104 12-14 metu amžiaus moksleiviai (68 orientacininkai ir 36 tu- ristai). Sportuojančių mokinių motyvacija nustatyta sporto motyvacijos skale (Pelletier et al., 1995). Sporto motyvacijos skalę sudaro 28 teiginiai, po keturis suskirstyti $\mathfrak{i} 7$ subskales, kurias sudaro: vidinè motyvacija - sužinoti; vidinè motyvacija - siekti tobulumo; vidiné motyvacija - patirti; išorinè motyvacija - identifikuotis, susitapatinti; išorinè motyvacija - nesąmoningai priimtas išorinis reguliavimas; išorinè motyvacija - tiesioginis išorinis reguliavimas; nemotyvuotumas. Atsakydami i kiekvieną teigini, tiriamieji turèjo pasirinkti atsakymo variantus penkiu pakopų Likerto skalèje nuo „visiškai nesutinku“ (1) iki „visiškai sutinku“ (5). Adaptuojant panašaus pobūdžio klausimynus kalbiniu ir kultūriniu aspektu, rekomenduojama ivertinti skaliu ir subskaliu vidini suderinamumą (Анастази, Урбина, 2001). Pažymėtina, kad vidinès konsistencijos Kronbacho alfa (Cronbach alpha) koeficientas daugelyje sporto motyvacijos skalès subskalių gerokai viršijo priimtiną 0,5 ribą ir svyravo nuo 0,58 iki 0,82 . Tyrimo rezultatai buvo vertinami analizuojant sporto motyvacijos skalès subskalių vidutinius įverčius ir pritarimo atskiriems teiginiams procentinius dažnius. Hipotezèms patikrinti buvo taikomas parametrinis Studento $t$ kriterijus nepriklausomoms imtims (Pukènas, 2005).

\section{REZULTATAI}

Išnagrinejjus orientavimosi sporto ir sportinio turizmo būrelių vadovų metinius veiklos planus, santykiškai galima išskirti devynias temų grupes, kurioms skiriamas nevienodas laikas (1 lent.). Orientavimosi sporto programos apima tris pagrindines temu grupes (orientavimosi techniką ir topografini rengimą; fizini rengimą; dalyvavimą varžybose ir panašioje veikloje, teisejjavima), kurioms skiriama $87,6 \%$ viso laiko. Sportinio turizmo būreliu programas sudaro penkios temos (turizmo technika; orientavimosi technika ir topografinis rengimas; fizinis rengimas; dalyvavimas varžybose ir panašioje veikloje, teisejjavimas; dalyvavimas stovyklose, žygiuose, ekskursijose, vakaronėse), kurioms skiriama $92,5 \%$ viso metinio laiko. Be to, sportinio turizmo būrelių veiklos plane orientavimosi technikai ir topografiniam rengimui skirta 10,6 $\pm 6,4 \%$ laiko. Orientavimosi būrelių veiklos planuose turizmo igūdžių lavinimas nenumatytas.

Vadinasi, galima teigti, kad sportinio turizmo būrelių programos yra išsamesnès, integruojančios daugiau skirtingų temų, didesnè temų ịvairové, 


\begin{tabular}{|l|c|c|}
\hline \multicolumn{1}{|c|}{ Ugdymo programos tema(-os) } & \multicolumn{2}{c|}{ Ugdymo programa } \\
\cline { 2 - 3 } & Orientavimosi sportas & Turizmas \\
\hline Ivadinės, organizacinės temos. Apibendrinimai. Saugumo temos & $2,1 \pm 0,2$ & $2,9 \pm 1,9$ \\
\hline Turizmo technika & $0,0 \pm 0,0$ & $27,6 \pm 15,0$ \\
\hline Orientavimosi technika ir topografinis rengimas & $40,1 \pm 9,7$ & $10,6 \pm 6,4$ \\
\hline Fizinis rengimas & $30,9 \pm 1,7$ & $20,7 \pm 4,4$ \\
\hline Dalyvavimas varžybose ir panašioje veikloje, teisëjavimas & $16,6 \pm 2,5$ & $12,9 \pm 4,5$ \\
\hline Dalyvavimas stovyklose, žygiuose, ekskursijose, vakaronėse & $3,5 \pm 6,4$ & $20,7 \pm 13,0$ \\
\hline Kraštotyrinis rengimas & $0,0 \pm 0,0$ & $2,8 \pm 3,3$ \\
\hline Psichologinis ir intelektinis rengimas & $4,9 \pm 2,2$ & $0,2 \pm 0,5$ \\
\hline Sveikatingumas ir savikontrolė & $1,9 \pm 0,7$ & $1,6 \pm 3,2$ \\
\hline
\end{tabular}

1 lentelè. Orientavimosi sporto ir sportinio turizmo programų temoms skiriamo laiko santykinès dalys (\%) $(\overline{\mathbf{X}} \pm \mathrm{SD})$

\begin{tabular}{|l|c|c|c|}
\hline \multicolumn{1}{|c|}{ Subskale } & \multicolumn{2}{c|}{ Ugdymo programa } & \multirow{2}{*}{$\boldsymbol{p}$} \\
\cline { 2 - 3 } & Orientavimosi sportas & Turizmas & \\
\hline VM - sužinoti & $3,97 \pm 0,76$ & $3,92 \pm 0,63$ & $>0,05$ \\
\hline VM - siekti tobulumo & $3,83 \pm 0,91$ & $3,98 \pm 0,65$ & $>0,05$ \\
\hline VM - patirti & $3,92 \pm 0,70$ & $4,08 \pm 0,58$ & $>0,05$ \\
\hline IM - identifikuotis, susitapatinti & $3,26 \pm 0,94$ & $3,25 \pm 0,73$ & $>0,05$ \\
\hline IM - nesąmoningai priimtas išorinis reguliavimas & $3,54 \pm 0,87$ & $3,56 \pm 0,75$ & $>0,05$ \\
\hline IM - tiesioginis išorinis reguliavimas & $2,77 \pm 1,07$ & $2,81 \pm 0,87$ & $>0,05$ \\
\hline Nemotyvuotumas & $2,19 \pm 0,96$ & $1,62 \pm 0,59$ & $<0,05$ \\
\hline
\end{tabular}

2 lentelè. Orientacininkų ir turistų sporto motyvacijos skalès subskalių iverčiai balais $(\overline{\mathbf{X}} \pm$ SD)

Pastaba. VM - vidinè motyvacija; IM - išorinè motyvacija.

orientavimosi sporto būrelių programos glaustesnès.

Analizuojant orientavimosi sporto ir sportinio turizmo būrelius pasirinkusių mokiniu pritarimo sporto motyvacijos skalès teiginiams duomenis nustatyta, kad šešiose subskalèse skirtumas tarp grupių yra nereikšmingas (2 lent.). Nemotyvuotumo subskalès teiginiams labiau pritarè orientacininkai nei turistai $(\mathrm{p}<0,05)$. Pažymėtina, kad šioje subskalejje apibendrinti teiginiai rodo abejojimą pasirinkta sporto šaka ir savo gebejjimais joje (pvz.: Dažnai savęs klausiu, kodèl sportuoju, juk nerealizavau tikslu, kuriu siekiau?).

Tiek orientavimosi, tiek sportinio turizmo būrelio mokiniai labiausiai pritarè pirmų triju subskalių teiginiams, kurie indikuoja vidinès motyvacijos apraiškas. Orientacininkų vidinių motyvų intensyvumas siekè 3,91 balo, turistų - 3,99. Reitingo viršūnę užèmè vidiniai motyvai, labiausiai susiję su kompetencijos igijimu. Motyvui Sportuoti man malonu, nes galiu igyti idomios patirties ir patirti nuotykiu pritare $91,2 \%$ orientacininkų ir 100\% turistų; motyvui Sportuoti man įdomu, nes išmokstu nauju pratimu ir treniravimosi metodu pritare $89,7 \%$ orientacininku ir $86,1 \%$ turistų; motyvui Sportuoti man idomu, nes daugiau sužinau apie sporta, kuriuo užsiimu - 85,3\% orientacininku ir $83,4 \%$ turistų. Pažymėtina, kad keturiais ir penkiais balais buvo išreiškiamas pritarimas anketos teiginiams. Paradoksalu, kad vidinès motyvacijos skalejje pritarimas teiginiui Sportuoju, nes jaučiu pasitenkinima, atlikdamas(-a) naujus ir sudètingus sporto pratimus buvo pats mažiausias. Šiam teiginiui pritarè 58,8\% orientacininku ir $61,1 \%$ turistų.

Išorinę motyvaciją indikuojančių subskalių vidutiniai įverčiai buvo kiek mažesni abiejose grupèse ir labiau telkèsi apie anketos atsakymo formuluotę ,nežinau“ (orientacininkų vidurkis 3,19 balo, turistų - 3,21). Pažymètina, kad dažniausiai pritarta teiginiui Sportuoju, nes norint büti geros formos bütina sportuoti (jam pritare $73,6 \%$ orientacininku ir $83,3 \%$ turistu). Pagal mokslininkų (Pelletier et al., 1995) modeli, kuriuo remiantis sukonstruota sporto motyvacijos skalè, šis teiginys priskiriamas subskalei „Išorinė motyvacija" - nesamoningai priimtas išorinis reguliavimas. Mažiausiai pritarta teiginiams, kurie atskleide akivaizdų išorini motyvavimą. Pavyzdžiui, teiginiui Sportuoju todèl, kad draugai ir kiti žmones už tai mane gerbia, vertina pritarė 29,4\% orientacininkų ir tik $13,9 \%$ turistų.

\section{REZULTATŲ APTARIMAS}

Apibendrinant tyrimo rezultatus galima teigti, kad ugdymo turinio ivairovė susijusi tik su sportuojančių mokinių nemotyvuotumu. Kuo didesnè ugdymo turinio îvairovè, tuo nemotyvuotumas mažesnis. Tai, kad orientavimosi sporto būreli lankantys mokiniai dažniau pritarè subskalès „Nemotyvuotumas“ teiginiams, priežastys galètų būti dar dvi. Pirma, skirtingas gero veiklos rezultato supratimas - geras orientacininkas yra tas, ,kuris per kuo trumpesnị laiką íveikia numatytą orientavimosi trasa“", o geras turistas ,dalyvauja iškylose, 
turistiniuose žygiuose ir pan.". Vienu atveju tikslą reikia pasiekti, kitu — pats dalyvavimas jau yra tikslas. Antra, veiklos sudettingumas ir pradedančiujų orientacininkų sportinių rezultatų nepastovumas. Dèl įvairių priežasčiu net ir talentingiems jauniesiems orientacininkams tenka suabejoti savo orientavimosi gebejjimais.

Tyrimo rezultatai leidžia formuluoti kelias svarbias prielaidas. Pirma, tyrimu atskleista, kad tokiame neformalaus sportinio regimo vyksme kaip orientavimosi sportas ir sportinis turizmas dalyvaujantys vaikai turi puikią vidinę motyvacija. Mokslininkai (Gilbertson et al., 2006) dažnai nurodo neformalaus sportinio ugdymo edukacinę jaunosios kartos poreikių tenkintojo vertę. Sportinis rengimas neformaliajame švietime jau pats savaime turiniu ir forma yra subtilus jaunos asmenybės ugdymo veiksnys. Orientavimosi sporto ir sportinio turizmo pratybos dažniausiai vyksta gryname ore, atveria palankias prielaidas ugdymo vyksme dvasiniam, humanistiniam ir pedocentriniam pradams pasireikšti. Be to, neformalia veiklą ugdytiniai renkasi savo noru ir lygiai taip pat gali ją palikti.

Kiti tyrèjai, nagrinėdami sportuojančių vaiku ir paauglių motyvaciją sportuoti, dažnai svarbiais nurodo būtent vidinius motyvus. N. Žilinskienė ir kt. (2007), tyrę socialinius ir sportinius veiksnius, skatinančius jaunus (13-17 metu) lengvaatlečius treniruotis, pažymi, kad daugumai besitreniruojančių mokinių svarbiau įdomios sporto pratybos, turiningas laisvalaikis, geri ir nuoširdūs santykiai su treneriu, draugais, negu noras būti žinomam ir gerbiamam. E. Grinienè ir S. Zablackaite (2007) nurodo, kad tarp motyvų, skatinančių mokinius sportuoti, populiariausiais noras stiprinti sveikatą. A. Šarkauskienè ir E. Adaškevičienè (2008) pažymi, kad 5-6 klasių mokinių pasirinkimą dalyvauti neformaliojo fizinio ugdymo vyksme labiausiai lemia vidinè motyvacija, o socialiniai veiksniai (draugu itaka, trenerių, mokytojų ir tėvu skatinimas) yra mažiau svarbūs.

Kita vertus, sportinis rengimas neformalaus švietimo požiūriu slepia savyje ir keletą pavojų. Sportinio rengimo vyksme, kaip niekur kitur ,iškyla prieštaravimas, kam teikti pirmenybę - geru sportinių rezultatų siekimui ar vaikų ir paaugliu asmenybės ugdymui(-si), suvokiant jos poreikius. Dažnai sporto būrelių trenerius kamuoja prieštaravimas, ką rinktis - atsižvelgti į ugdytinių poreikius, interesus, motyvus ar siekti puikių sportiniu rezultatų. Šis prieštaravimas kelia pavojuc, nes dažnai nepaisoma vaiku interesu ir pirmenybė atiduodama sportinio rezultato siekimui, smarkiai siaurinant ir specializuojant ugdymo turini, išorinius ir vidinius motyvus sukeičiant vietomis.

Mokslininkai (Green-Demers et al., 1998; A1derman et al., 2006), nors ir netiesiogiai, pasisako už didesnę priemonių ir metodų ívairovę. Štai I. Green-Demers ir kt. (1998) pažymi, kad patys sportininkai ir jų treneriai naudojasi keliomis motyvacijos strategijomis nuoboduliui iveikti: iššūkio (pa-)didinimu, varijavimu, atliekamo pratimo îvairove, racionalizavimu, savęs itikinimu ir skatinančios aplinkos ar konteksto panaudojimu. B. L. Alderman ir kt. (2006) nurodo tris pagrindines strategijas, kuriomis vadovaujantis galima didinti mokinių vidinę motyvaciją per fizinio ugdymo vyksmą - tai galimybė rinktis, individualizavimas, optimalus iššukis atliekant kiekvieną pratimą.

Vertinant tyrimo rezultatus ir numatant tolesnių tyrimu perspektyvas reikètu atkreipti dèmesi i tai, kad šio tyrimo metu nagrinètas formalus turinys, yra tas ugdymo programos turinys, kuris pateikiamas dokumentuose. O formalus ugdymo turinys, akivaizdu, nevisiškai atskleidžia realią ugdymo praktiką. Pavyzdžiui, prityręs treneris ir formaliai skurdų ugdymo programos turini gali realizuoti labai virtuoziškai, įdomiai, puikiai paveikdamas jaunujų sportininkų vidinę motyvaciją. Be to, anot B. Bitino (2006), pavienio edukologinio tyrimo sprendinys negali išspręsti ugdymo problemos, todèl klausimas, kiek ugdymo turinio ivvairovė lemia vaikų motyvaciją sportuoti, lieka tik iš dalies atsakytas. Ateityje būtina vykdyti išsamesnius tyrimus, itraukiant daugiau sporto šaku ir tiriamujų. Būtina vertinti ne tik formalaus, bet ir realaus ugdymo turinio ivvairovę. Taip pat atlikti eksperimentinius tyrimus, tiksliai kontroliuojant nepriklausomą kintamaji - ugdymo turinio metodų ir priemoniu ivvairovę.

\section{IŠVADA}

Esant didesnei ugdymo ívairovei, ugdytinių nemotyvuotumas yra mažesnis. Moksleiviai, lankantys sportinio turizmo būrelius, mažesnio nemotyvuotumo nei orientavimosi sporto grupiu tiriamieji. Šis skirtumas sietinas su ugdymo turinio ivvairove, skirtingu veiklos pobūdžiu ir tikslais. Sportinio turizmo ir orientavimosi sporto būrelius lankantys moksleiviai turi daugiau vidinių motyvų sportuoti nei išorinių. 


\title{
LITERATŪRA
}

Alderman, B. L., Beighle, A., Pangrazi, R. P. (2006). Enhancing motivation in physical education. Journal of Physical Education, Recreation and Dance, 77 (2), $41-45,51$.

Anderssen, N., Wold, B., Torsheim, T. (2005). Tracking of physical activity in adolescence. Research Quarterly for Exercise and Sport, 76 (2), 119-129.

Bitinas, B. (2006). Edukologinis tyrimas: sistema ir procesas. Vilnius: Kronta.

Chen, A., Ennis, C. D. (2004). Goals, interests, and learning in physical education. Journal of Educational Research, 97 (6), 329-338.

Dollman, J., Olds, T., Norton, K., Stuart, D. (1999). The evolution of fitness and fatness in 10-11-year-old Australian schoolchildren: Changes in distributional characteristics between 1985 and 1997. Pediatric Exercise Science, $11,108-121$.

Gilbertson, K., Bates, T., McLaughlin, T., Ewert, A. (2006). Outdoor Education: Methods and Strategies. Champaign, IL: Human Kinetics.

Green-Demers, I., Pelletier, L. G., Stewart, D. G., Gushue, N. R. (1998). Coping with the less interesting aspects of training: Toward a model of interest and motivation enhancement in individual sports. Basic and Applied Social Psychology, 20 (4), 251-261.

Grinienè, E., Zablackaitè, S. (2007). Sportuojančių 16-18 metų mokiniu gyvenimo kokybė. Sporto mokslas, 3 (49), $60-66$.

Hallal, P. C., Victora, C. G., Azevedo, M. R., Wells, J. C. K. (2006). Adolescent physical activity and health. Sports Medicine, 36 (12), 1019-1030.

Hardy, L., Jones, G., Gould, D. (2003). Understanding Psychological Preparation for Sport: Theory and Practice of Elite Performers. New Jersey: John Wiley \& Sons.

Malinauskas, R. (2003 a). Didelio meistriškumo dvikovos sporto šakų sportininkų ir jų rezervo motyvacijos ypatu- mai. Sporto mokslas, 1 (31), 19-23.

Malinauskas, R. (2003 b). Sporto psichologijos pagrindai: studiju knyga. Kaunas: LKKA.

Malinauskas, R. (1998). Vaikinu, kurie renkasi boksą, motyvacijos ypatumai. Sporto mokslas, 3 (12), 20-22.

Pelletier, L. G., Fortier, M. S., Vallerand, R. J. et al. (1995). Toward a new measure of intrinsic motivation, extrinsic motivation, and amotivation in sports: The Sport Motivation Scale (SMS). Journal of Sport and Exercise Psychology, 17, 35-53.

Pukènas, K. (2005). Sportiniu tyrimu analizè SPSS programa: mokomoji knyga. Kaunas: LKKA [žiūrèta 2006-1119]. Prieiga internetu: $<$ http://www.lkka.lt/PSK $>$.

Ryan, R. M., Deci, E. L. (2007). Active human nature. Self-determination theory and the promotion and maintenance of sport, exercise, and health. In M. S. Hagger, N. L. D. Chatzisarantis (Eds.), Intrinsic Motivation and Self-determination in Exercise and Sport (pp. 1-19). Champaign, IL: Human Kinetics.

Šarkauskienė, A., Adaškevičienė, E. (2008). 5-6 klasių mokiniu neformaluji fizini ugdyma lemiantys veiksniai. Ugdymas. Küno kultūra. Sportas, 3 (70), 88-94.

Vallerand, R. J. (2007). A hierarchical model of intrinsic and extrinsic motivation for sport and physical activity. In M. S. Hagger, N. L. D. Chatzisarantis (Eds.), Intrinsic Motivation and Self-determination in Exercise and Sport (pp. 255-279). Champaign, IL: Human Kinetics.

Weinberg, M. D., Gould, D. (2006). Foundations of Sport and Exercise Psychology. Champaign, IL: Human Kinetics.

Žilinskienė, N., Tubelis, L., Radžiukynas, D. (2007). Socialiniai, sportiniai veiksniai, skatinantys treniruotis jaunus lengvaatlečius. Sporto mokslas, 3 (49), 52-59.

Анастази, А., Урбина, С. (2001). Психологическое тестирование. Санкт-Петербург: ПИТЕР. С. 117.

\section{DIVERSITY OF THE CONTENT OF EDUCATION AS A FACTOR ENCOURAGING LEARNERS' MOTIVATION TO PARTICIPATE IN SPORTS}

\author{
Lauras Grajauskas ${ }^{1}$, Algirdas Čepulènas ${ }^{2}$ \\ Šiauliai University ${ }^{1}$, Šiauliai, Lithuanian Academy of Physical Education ${ }^{2}$, Kaunas, Lithuania
}

\begin{abstract}
The content of education is a very important factor influencing learners' motivation. However, the link between the diversity of sports education content and learners' motivation for sports has not been adequately researched. It has been more often studied in the context of formal education, and in the informal education it is usually described theoretically and not grounded empirically. The aim of the present research was to reveal the links between the diversity of the content of informal education and learners' motivation to participate in sports.

First we studied the annual plans of two informal education clubs similar in their activities - six clubs of orienteering sport and four clubs of tourism. According to the topics and their content we distinguished
\end{abstract}


groups of activity topics and analyzed the quantitative and qualitative differences in the activities of those clubs. Then we investigated the learners' motivation to participate in those sports. The research participants were 104 12-14 year-old schoolchildren (68 orienteerers and 36 tourists). Motivation was assessed applying the Sports Motivation Scale (Pelletier et al., 1995).

It was established that programs of tourism clubs were wider, integrating more different topics and displaying a greater content diversity. The programs of the orienteering clubs were more concentrated. The differences between the groups in six sports motivation subscales were not statistically significant, but the statements in the motivelessness scale were more supported $(\mathrm{p}<0.05)$ by orienteerers $(2.19 \pm 0.96$ points $)$ compared to tourists $(1.62 \pm 0.59$ points $)$. The learners in both clubs more agreed to the statements of the first three scales which indicated the manifestation of internal motivation (the intensity of the internal motivation of orienteerers was 3.91 points and that of tourists - 3.99 points). The mean values of the subscales indicating external motivation were lower in both groups and more massed to the answer "I do not know" (the mean value of orienteerers was 3.19, and that of tourists - 3.21).

Summing up we suggest that the diversity of the education content is linked only to the amotivation of learners engaged in sports. When the diversity of the education content is greater, the amotivation is lower.

Keywords: informal education, motivation, education content, diversity.

Gauta 2008 m. gruodžio 29 d.

Received on December 29, 2008

Priimta $2009 \mathrm{~m}$. kovo $5 \mathrm{~d}$.

Accepted on March 5, 2009

\author{
Lauras Grajauskas \\ Šiaulių universitetas \\ (Šiauliai University) \\ P. Višinskio g. 25, LT-76351 Šiauliai \\ Lietuva (Lithuania) \\ Tel +370 62049660 \\ E-mail laurasgrajauskas@gmail.com
}

